\title{
Article \\ Severe Late-Onset Grade III-IV Adverse Events under Immunotherapy: A Retrospective Study of 79 Cases
}

\author{
Jean-Matthieu L'Orphelin ${ }^{1, *(\mathbb{C})}$, Emilie Varey ${ }^{2}$, Amir Khammari $^{2}$, Brigitte Dreno $^{2}$ and Anne Dompmartin ${ }^{1}$ \\ 1 Department of Dermatology, Caen-Normandie University Hospital, 14003 Caen, France; \\ anne.dompmartin@gmail.com \\ 2 Department of Dermatology, CHU Nantes, CIC 1413, CRCINA, Nantes University, 44200 Nantes, France; \\ e.varey@chu-caen.fr (E.V.); a.khammari@chu-caen.fr (A.K.); brigitte.dreno@atlanmed.fr (B.D.) \\ * Correspondence: lorphelin-jm@chu-caen.fr; Tel.: +33-(0)2-31-27-25-10
}

check for updates

Citation: L'Orphelin, J.-M.; Varey, E.; Khammari, A.; Dreno, B.; Dompmartin, A. Severe Late-Onset Grade III-IV Adverse Events under Immunotherapy: A Retrospective Study of 79 Cases. Cancers 2021, 13, 4928. https://doi.org/10.3390/ cancers13194928

Academic Editors: Samia Mourah and Barouyr Baroudjian

Received: 27 August 2021

Accepted: 27 September 2021

Published: 30 September 2021

Publisher's Note: MDPI stays neutral with regard to jurisdictional claims in published maps and institutional affiliations.

Copyright: (C) 2021 by the authors Licensee MDPI, Basel, Switzerland This article is an open access article distributed under the terms and conditions of the Creative Commons Attribution (CC BY) license (https:// creativecommons.org/licenses/by/ $4.0 /)$.
Simple Summary: PD-1 inhibitors (nivolumab, pembrolizumab) and anti-CTLA-4 (CD152) (ipilimumab) are widely used in metastatic melanoma. Immunotherapy leads to prolonged lymphocyte effects, which explains the cytotoxicity underlying immune-reaction-based adverse events. Most adverse events (irAEs) occur in the first cycle of treatment at a median of 40 days, but some occur later, over 2 years after immunotherapy is initiated. IrAEs of any grade have been observed in $68.2 \%$ of patients and $10 \%$ of patients experienced severe grade III/IV irAEs. Data on late-onset irAEs are lacking. We aim to investigate late-onset grade III-IV irAEs and patient characteristics in the context of anti-PD-1 antibody treatment or combination therapy in real-life settings.

Abstract: Background: For several decades, PD-1 has been a target in malignant melanoma (MM). PD-1 inhibitors (nivolumab, pembrolizumab) and anti-CTLA-4 (CD152) (ipilimumab) have revolutionized cancer therapy. PD-1 and CTLA-4 inhibition leads to prolonged lymphocyte effects, which explains the cytotoxicity underlying immune-reaction-based adverse events (irAEs). Most irAEs occur in the first cycle of treatment at a median of 40 days. IrAEs of any grade have been observed in $68.2 \%$ of patients, with $10 \%$ of patients experiencing severe grade III/IV irAEs. Data on late-onset irAEs are lacking. Methods: Data on patients with advanced melanoma $(N=1862)$ from March 2016 to March 2021 were obtained from the RicMel database, a French national multicentric biobank dedicated to the follow-up of MM patients. Patients who received anti-PD-1 therapy or a combination therapy and experienced grade III-IV irAEs were selected and analyzed at 7 months, one year and two years after treatment was initiated. Results: Superficial spreading melanoma (SSM) and previous oncological drug administration before immunotherapy are significant risk factors for late-onset irAEs over 2 years after beginning immunotherapy in the univariate and multivariate analysis. The other parameters-sex, mutational status, association of immunotherapy (PD-1i and CTLA-4i) and overall response-were not significantly associated with late-onset irAEs. In our real-life data study, the median onset time of grade III-IV irAES was 128 days after the initiation of immune checkpoint inhibitors (ICI) therapy. Conclusions: Our study, using real-life data, suggests that patients with SSM and those who have received previous oncological treatments are more likely to experience late-onset grade III-IV irAES. Further multicentric studies with wider recruitment of patients should be performed to confirm our findings, potentially leading to changes in the recommended treatment for carefully monitored at-risk patients.

Keywords: melanoma; adverse events; immunotherapy

\section{Introduction}

Malignant melanoma (MM) develops from pigment-containing cells known as melanocytes [1] and represents 2 to 3\% of cancers [2]. The incidence rate of MM increased the most among all cancers (+371\%) between 1990 and 2018, with 15,513 cases in France in 2019. 
Evidence suggests that a functional immune system can act in a self-perpetuating mechanism to eliminate or durably control melanoma [3,4]. Immune checkpoints regulate the outcome of lymphocyte engagement with antigen-presenting cells and tumor cells [5], downmodulating the intensity of adaptive immune responses, which provides a spectrum of potential new targets for cancer immunotherapy.

Programmed cell death 1 (PD-1) is a key inhibitory receptor expressed by activated T and B cells. PD-1 inhibits the proliferation of immune cells that downmodulate effector functions [4,6] and promote self-tolerance. [1]. PD-L1 (B7-H1) is expressed in nonlymphoid tissues [7], whereas its expression is upregulated in MM [8]. Engagement of PD-1 by PD-L1 leads to the inhibition of T-cell receptor-mediated lymphocyte proliferation and cytokine secretion [7], consequently increasing tolerance. The blockade of PD-1-PD-L1 interaction is an effective approach for MM treatment [9]. PD-1 inhibitors, such as nivolumab, pembrolizumab [10] and ipilimumab (anti-CTLA-4 or CD152), also block prototypical T-cell checkpoints and have revolutionized cancer therapy [11,12].

PD-1 and CTLA-4 inhibition lead to continued and prolonged lymphocyte effects, which explains the cytotoxicity underlying immune-reaction-based adverse events (irAEs). Most adverse events occur in the first cycle of treatment at a median of 40 days [13]. Gastrointestinal, skin and potential irAEs leading to hyperglycemia and thyroid, hepatic and musculoskeletal disorders have been observed following nivolumab and pembrolizumab therapy [14]. IrAEs of any grade have been observed in $68.2 \%$ of patients with nivolumab, whereas potentially severe grade III/IV irAEs have been found to be experienced by approximately $10 \%$ of patients $[15,16]$.

PD-1i treatment is stopped if a one-year complete response is achieved or tumor resistance occurs. Despite licensing for long-term use, optimal treatment duration is unknown even if some studies propose to stop the treatment for melanoma patients receiving anti-PD-1 therapy who are progression-free (confirmed by positron emission tomography (PET), coupled or not with tomodensitometry (TDM) at 12 months and with normal LDH) to avoid life-changing and life-threatening immune-mediated toxicities [17]. Nevertheless, some patients receive treatment for several years and data on late-onset irAEs are lacking.

The aim of this study was to investigate severe late-onset irAEs, i.e., grade III-IV irAEs, and patient characteristics in the context of anti-PD-1 antibody treatment or combination therapy in real-life settings.

\section{Materials and Methods}

Data on patients with advanced melanoma $(N=1862)$ from March 2016 to March 2021 were obtained from the RicMel database, a French national multicentric database dedicated to the follow-up of MM patients. Patients who received intravenous anti-PD-1 therapy or a combination of PD-1 and anti-CTLA4 were selected, and the occurrence of irAEs, the number of perfusions and overall survival rates were analyzed.

The RicMel database (Clinical Trials $n^{\circ}$. NCT03315468) gathers data from 49 participating centers in different French regions. It received ethics committee approval on February 9th, 2012 (no. 12.108) from the Independent Ethics Committee in Paris and received authorization from the French Data Protection Agency (CNIL, DR-2012-259, 28 May 2012).

The inclusion criteria were as follows:

- $\quad$ Patients with unresectable stage IV MM;

- $\quad$ Patients treated with anti-PD-1 or combination therapy

- $\quad$ Patients who experienced grade III-IV irAEs with the administered IT.

RicMel is a declarative French database. All irAEs have been previously studied by local pharmacovigilance surveys to rule out the imputability of immunotherapy from the medical field.

After screening the RicMel database, complementary medical data were collected for the included patients at the Nantes University Hospital. We reported 79 grade III/IV irAEs 
due to PD-1i according to standard guidelines, such as the CTCAE (Common Terminology Criteria for Adverse Events). The grading of irAEs was determined by treating physicians (dermatologists and/or oncologists) and reviewed by a physician from the RicMel database. All baseline characteristics are summarized in Table 1.

Table 1. Patient characteristics.

\begin{tabular}{|c|c|}
\hline Baseline Characteristics & $\begin{array}{l}\text { All Cases } \\
(n=79)\end{array}$ \\
\hline Age (years), mean \pm std & $69.5 \pm 13.9$ \\
\hline \multicolumn{2}{|l|}{ Sex, $n(\%)$} \\
\hline Male & $41(52)$ \\
\hline Female & $38(48)$ \\
\hline \multicolumn{2}{|l|}{ Type of melanoma, $n(\%)$ * } \\
\hline NM & $15(19)$ \\
\hline SSM & $30(38)$ \\
\hline Ocular & $4(5)$ \\
\hline ALM & $2(3)$ \\
\hline LMM & $5(6)$ \\
\hline MLM & $7(9)$ \\
\hline Unknown primitive & $7(9)$ \\
\hline Other & $9(11)$ \\
\hline \multicolumn{2}{|l|}{ Mutation status, $n(\%)$} \\
\hline NRAS & $31(39)$ \\
\hline BRAF & $11(14)$ \\
\hline NRAS + CKIT & $2(3)$ \\
\hline Wild & $35(44)$ \\
\hline \multicolumn{2}{|l|}{ Immunotherapy, $n(\%)$} \\
\hline Nivo & $63(80)$ \\
\hline Ipi + Nivo & $15(19)$ \\
\hline Pembro & $1(1)$ \\
\hline \multicolumn{2}{|l|}{ Line, $n(\%)$} \\
\hline 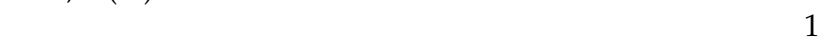 & $30(38)$ \\
\hline 2 & $24(30)$ \\
\hline 3 & $16(20)$ \\
\hline$\geq 4$ & $9(11)$ \\
\hline Duration of actual immunotherapy (days), median (IQR) & $146(85-255)$ \\
\hline Previously treated by PD1i, $n(\%)$ & $29(37)$ \\
\hline \multicolumn{2}{|l|}{ Overall response rate (ORR), $n(\%) * *$} \\
\hline CR Complete response & $16(25)$ \\
\hline S Stability & $12(18)$ \\
\hline PR Partial response & $11(17)$ \\
\hline P Progression & $26(40)$ \\
\hline
\end{tabular}

* NM: nodular melanoma; SSM: Superficial Spreading Melanoma; Ocular: Ocular melanoma; ALM: Acro Lentiginous melanoma; LMM: Lentigo Malignant Melanoma; MLM: MucosalLentiginous Melanoma; Other: not classifiable (4) or not specified (4) or desmoplastic (1); ${ }^{* *}$ Data missing for 14 patients.

Details of 79 grade III/IV irAEs are listed in Table 2. 
Table 2. Characteristics and consequences of irAEs.

\begin{tabular}{|c|c|c|}
\hline Characteristics & $\begin{array}{l}\text { All Cases } \\
(n=79)\end{array}$ & $\begin{array}{c}\text { Late-Onset AEs } \\
(\geq 2 \text { Years }) \\
(n=4)\end{array}$ \\
\hline \multicolumn{3}{|l|}{ Type of AEs, $n(\%)$} \\
\hline Cardiology & $\begin{array}{c}\qquad 3(4) \\
\text { Atrioventricular block, Myocarditis (2) }\end{array}$ & $\begin{array}{c}1(25) \\
\text { Myocarditis }\end{array}$ \\
\hline Hepatogastroenterology & $\begin{array}{c}37(47) \\
\text { Immune colitis (15), Diarrhea (2), Cholangitis (7), Hepatitis (13) }\end{array}$ & $\begin{array}{c}1(25) \\
\text { Hepatitis }\end{array}$ \\
\hline General & $\begin{array}{c}5(6) \\
\text { Asthenia (3), Multiple organ failure, Hypernatremia }\end{array}$ & \\
\hline Hematology & $\begin{array}{c}2(2) \\
\text { Anemia, Hyper eosinophilia }\end{array}$ & \\
\hline Immunology & $\begin{array}{c}3(4) \\
\text { Hypophysis (2), acute GvH }\end{array}$ & \\
\hline Musculoskeletal system & $\begin{array}{c}4(5) \\
\text { Myalgia, Myasthenia, Arthralgia, Elevation of CPK }\end{array}$ & \\
\hline Ophthalmology & $\begin{array}{l}1(1) \\
\text { Optic retrobulbar neuritis }\end{array}$ & $\begin{array}{l}1(25) \\
\text { Optic retrobulbar neuritis }\end{array}$ \\
\hline Dermatology & $\begin{array}{c}12 \text { (15) } \\
\text { Pruritus (3), Rash (5), Carcinoma, SJS, Bullous pemphigoid (2) }\end{array}$ & $\begin{array}{l}1(25) \\
\text { Pruritus }\end{array}$ \\
\hline Pneumology & $\begin{array}{c}5(6) \\
\text { Immune pneumonitis (4), Pulmonary embolism }\end{array}$ & \\
\hline Nephrology & $\begin{array}{c}3(4) \\
\text { Acute renal failure, Tubulointerstitial nephritis (2) }\end{array}$ & \\
\hline Neurology & $\begin{array}{c}4(5) \\
\text { Apraxia, Demyelinating neuropathy, Neuropathy, Unknown }\end{array}$ & \\
\hline \multicolumn{3}{|l|}{ Grade, $n(\%) *$} \\
\hline 3 & $70(88)$ & $2(50)$ \\
\hline 4 & $9(12)$ & $2(50)$ \\
\hline \multicolumn{3}{|l|}{ Sequelae, $n(\%) *$} \\
\hline Yes (except death) & $12(19)$ & $2(67)$ \\
\hline Death & $2(3)$ & $0(0)$ \\
\hline No & $50(78)$ & $1(33)$ \\
\hline
\end{tabular}

Details of 15 grade III/IV irAEs occurring after at least one year of ICI initiation are listed in Table 3 with details on the management of irAEs and recovery time. 
Table 3. Focus on late-onset irAEs ( $>1$ year, $n=15$ ) of which 4 late-onset irAES $>2$ years.

\begin{tabular}{|c|c|c|c|c|c|c|c|c|}
\hline & Type of irAES & Grade & ICI & $\begin{array}{l}\text { Delay after ICI } \\
\text { Initiation (Days) }\end{array}$ & $\begin{array}{c}\text { Melanoma } \\
\text { Characteristics } \\
\text { (Type, } \\
\text { Mutational Status) }\end{array}$ & $\begin{array}{l}\text { Previous Systemic Treatment } \\
\text { (Duration, Days) }\end{array}$ & Management of irAEs & $\begin{array}{l}\text { Time to Recover and } \\
\text { Sequelae }\end{array}$ \\
\hline Case 1 & Pruriginous rash & 3 & Nivo & 374 & MLM, BRAF & Vemurafenib-Cobimetinib (125) & $\begin{array}{l}\text { Topical medication + } \\
\text { Antihistamine + } \\
\text { steroids }\end{array}$ & No, pruritus persistence \\
\hline Case 2 & Cholestasis & 3 & Nivo & 376 & SSM, wild type & $\begin{array}{l}\text { IFN } \alpha(94) / \text { Dacarbazine } \\
\text { (350)/Ipilimumab (96) }\end{array}$ & / & Yes, grade I at 156 days \\
\hline Case 3 & Hepatitis & 3 & Nivo & 393 & SSM, wild type & No previous systemic treatment & $\begin{array}{l}\text { Steroids per os and } \\
\text { Cellcept (500 mgx2 } \\
\text { per day) }\end{array}$ & $\begin{array}{l}\text { No, still with steroids and } \\
\text { hepatic disurbance } \\
\text { when deceased }\end{array}$ \\
\hline Case 4 & $\begin{array}{l}\text { Multiple organ } \\
\text { failure }\end{array}$ & 4 & Nivo & 402 & SSM, NRAS & Pimasertinib (506) & $\begin{array}{l}\text { Death before any } \\
\text { treatment initiation }\end{array}$ & No recover \\
\hline Case 5 & Cholestasis & 4 & Nivo & 409 & SSM, wild type & Dacarbazine (192)/Nivolumab (170) & Steroids per os & Yes, at 25 days \\
\hline Case 6 & Immune pneumotitis & 3 & Nivo & 467 & SSM, BRAF & $\begin{array}{l}\text { IFN } \alpha \text { (534)/Dabrafenib-Tramétinib } \\
\text { (89)/Vemurafenib-Cobimetinib (28) }\end{array}$ & / & Yes, at 44 days \\
\hline Case 7 & $\begin{array}{l}\text { Pulmonary } \\
\text { embolism }\end{array}$ & 3 & Nivo & 478 & NM, wild type & IFN $\alpha$ (117)/Ipilimumab (79) & $\begin{array}{l}\text { Innohep SC } \\
0.8 \mathrm{~mL} / \text { day }\end{array}$ & No recover \\
\hline Case 8 & Apraxia & 3 & Nivo & 499 & SSM, NRAS & Pimasertinib (338)/Ipilimumab (175) & $\begin{array}{l}\text { Bolus of steroids IV + } \\
\text { Ig IV + Riuximab } \\
\quad \text { (4 cures })\end{array}$ & $\begin{array}{l}\text { No recover: cerebellar } \\
\text { syndrome persistence }\end{array}$ \\
\hline Case 9 & Immune colitis & 3 & Ipi-Nivo & 523 & SSM, NRAS & $\begin{array}{c}\text { IFN } \alpha \text { (168)/Carboplatine-Dacarbazine } \\
\text { (155)/Ipilimumab (156) }\end{array}$ & Steroids and remicade & Yes, at 72 days \\
\hline Case 10 & $\begin{array}{l}\text { Hepatitis and } \\
\text { immune colitis }\end{array}$ & 3 & Nivo & 533 & LMM, wild type & $\begin{array}{l}\text { Experimental treatment (Radiotherapy + } \\
\text { chloroquine (97))/Ipilimumab (65) }\end{array}$ & / & Yes, at 25 days \\
\hline Case 11 & Hepatitis & 3 & Nivo & 589 & NM, wild type & $\begin{array}{c}\text { IFN } \alpha \text { (813)/T-VEC (924)/Nivolumab } \\
\text { (182)/Dacarbazine (88) }\end{array}$ & / & No recover \\
\hline Case 12 & Myocarditis & 4 & Nivo & 759 & SSM, wild type & No previous systemic treatment & Steroids IV $2 \mathrm{mg} / \mathrm{kg}$ & $\begin{array}{l}\text { No, high troponine } \\
\text { persistence }\end{array}$ \\
\hline Case 13 & Pruritus & 3 & Pembro & 900 & ALM, NRAS & $\begin{array}{l}\text { Experimental treatment (MERCK NCT } \\
\text { 01866319) (121)/Pembrolizumab } \\
\text { (99)/Carboplatine-Dacarbazine } \\
\text { (202)/Dacarabzine } \\
\text { (338)/Carboplatine-Dacarbazine (57) }\end{array}$ & $\begin{array}{c}\text { Topical medication + } \\
\text { Antihistamine + lyrica } \\
300 \mathrm{mg} / \text { days }\end{array}$ & Yes, at 42 days \\
\hline Case 14 & $\begin{array}{l}\text { Optic retrobulbar } \\
\text { neuritis }\end{array}$ & 3 & Nivo & 1249 & SSM, NRAS & $\begin{array}{c}\text { IFN } \alpha(280) / \text { Nivolumab (113)/Dacarbazine } \\
\text { (109)/Nivolumab (101)/Experimental } \\
\text { treatment (BMS 224-022 Anti-LAG3 + } \\
\text { Nivolumab) (532))/Nivolumab } \\
\text { (112)/Dacarbazine (140) }\end{array}$ & $\begin{array}{l}\text { Bolus of steroids IV } \\
\text { and low dose steroids } \\
\text { basal }\end{array}$ & $\begin{array}{l}\text { No recover: visual acuity } \\
\text { reduction persistence }\end{array}$ \\
\hline Case 15 & Hepatitis & 4 & Nivo & 1375 & SSM, wild type & Dacarbazine (192)/Nivolumab (399) & Steroids per os & Yes, at 38 days \\
\hline
\end{tabular}




\section{Statistical Analysis}

We performed a Kaplan-Meier analysis of severe grade III-IV irAEs (event of KM curve) to confirm that most of these events occurred during the first months of treatment. We initially analyzed all grade III-IV irAEs and subsequently focused on late-onset irAEs, i.e., irAEs arising after 6 months. Thus, we performed statistical analyses of irAEs at 7 months, 1 year and 2 years.

All significant parameters in the univariate analysis were further analyzed using a multivariate analysis to determine if the parameters were independent of each other.

\section{Results}

The median onset time of our 79 grade III-IV irAES was 128 days after the initiation of ICI therapy. Irrespectively of delay appearance, the most common irAEs we reported were hepatogastroenterologic $(n=37,47 \%)$, dermatologic $(n=12,15 \%)$ and pneumological $(n=5,6 \%)$. Most of the events were grade III irAES $(n=70,88 \%)$, with only $9(12 \%)$ grade IV irAEs.

The KM curve analysis (Figure 1) revealed that most events (i.e., grade III-IV irAEs due to immunotherapy) occur before 7 months, with $75 \%$ of events occurring before 214 days (7 months). At 7 months, 1 year and 2 years, we observed 20, 15 and 4 events, respectively. [Figure 1 near here]

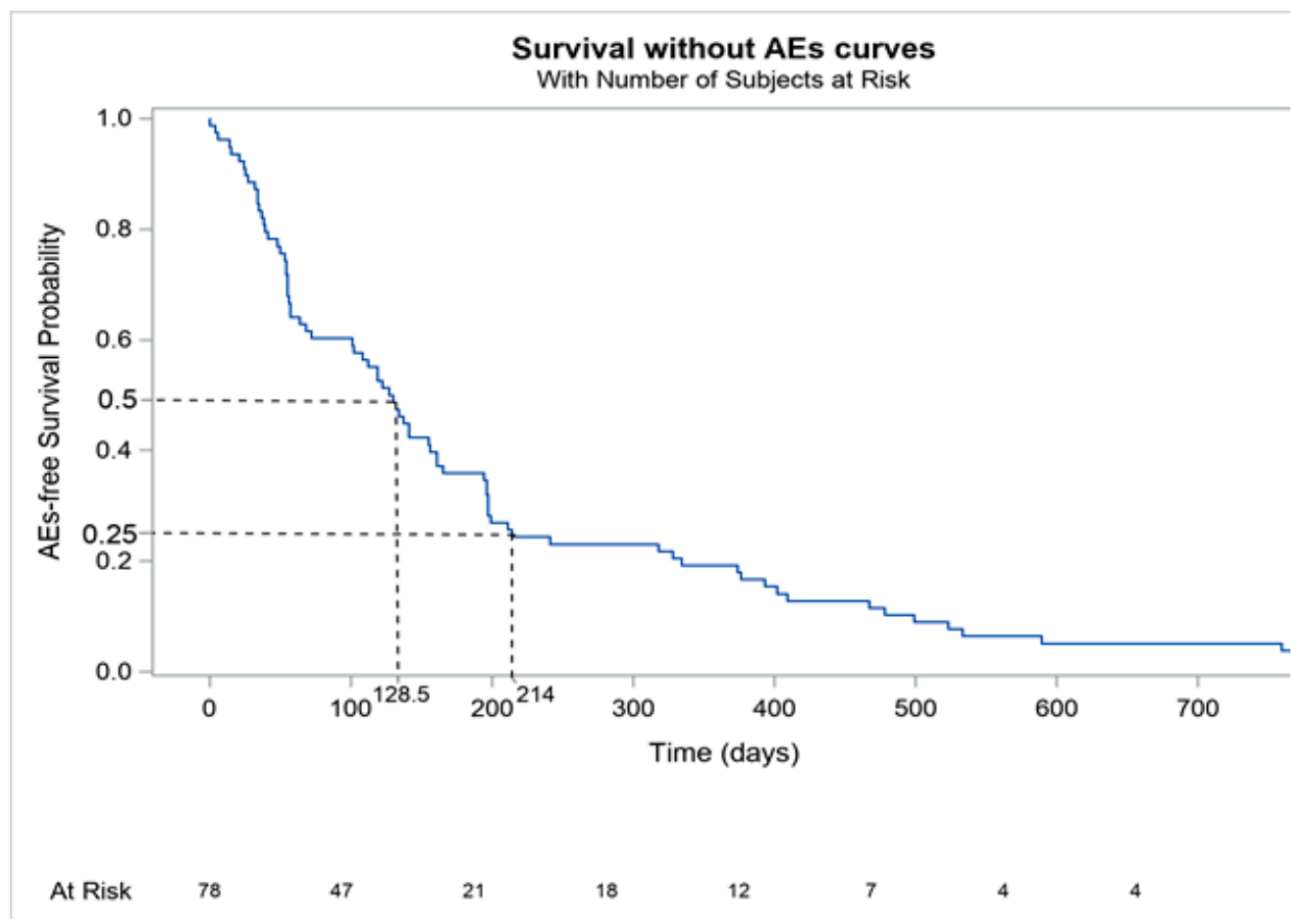

Figure 1. Kaplan-Meier analysis of severe grade III-IV irAEs.

Four late-onset irAEs occurred over 2 years in our cohort of 79 cases:

- $\quad$ One SSM wild-type patient experienced grade IV myocarditis that occurred with nivolumab 759 days after the initiation of immunotherapy;

- $\quad$ One ALM NRAS patient experienced grade III pruritus with pembrolizumab that occurred 900 days after the initiation of immunotherapy;

- $\quad$ One SSM NRAS patient experienced grade III optic neuritis with nivolumab that occurred 1249 days after the initiation of immunotherapy;

- $\quad$ One SSM wild-type patient experienced grade IV hepatitis with nivolumab that occurred 1375 days after the initiation of immunotherapy. 
All factors associated with late-onset events ( 7 months, 1 year, 2 years), as identified by the univariate analysis, are summarized in Table 4.

Table 4. Factors associated with late-onset events (7 months, 1 year, 2 years) by univariate analysis ( $n$ : number of patients with AEs at that time point; OR: odds ratio; $95 \% \mathrm{CI}=1: 95 \%$ confidence interval; $p$ : $p$-value for univariate logistic regression).

\begin{tabular}{|c|c|c|c|c|c|c|c|c|c|}
\hline \multirow{2}{*}{ Characteristics } & \multicolumn{3}{|c|}{ Late-Onset AEs ( $\geq 2$ Years, $n=4)$} & \multicolumn{3}{|c|}{ Late-Onset AEs ( $\geq 1$ Years, $n=15$ ) } & \multicolumn{3}{|c|}{ AEs ( $\geq 7$ Months, $n=20)$} \\
\hline & OR & $95 \%$ CI & $p$ & OR & $95 \% \mathrm{CI}$ & $p$ & OR & $95 \% \mathrm{CI}$ & $p$ \\
\hline Age (years) & 1.03 & $(0.94-1.12)$ & 0.578 & 0.99 & $(0.95-1.03)$ & 0.545 & 0.97 & $(0.93-1.00)$ & 0.068 \\
\hline Age $>75$ yo & 0.59 & $(0.06-5.98)$ & 0.658 & 0.61 & $(0.17-2.12)$ & 0.433 & 0.52 & $(0.17-1.63)$ & 0.264 \\
\hline Male & 0.29 & $(0.03-2.93)$ & 0.296 & 0.77 & $(0.25-2.38)$ & 0.653 & 0.90 & $(0.33-2.49)$ & 0.845 \\
\hline \multicolumn{10}{|c|}{ Type of melanoma } \\
\hline NM vs. others & \multicolumn{2}{|c|}{ Not available } & 0.969 & 0.60 & $(0.12-3.02)$ & 0.539 & 0.69 & $(0.17-2.75)$ & 0.601 \\
\hline SSM vs. others & 5.33 & $(0.53-53.83)$ & 0.156 & 4.40 & $(1.33-14.56)$ & 0.016 & 3.42 & $(1.19-9.79)$ & 0.023 \\
\hline Multiple metastatic sites & 0.53 & $(0.05-5.33)$ & 0.589 & 2.18 & $(0.70-6.81)$ & 0.180 & 1.12 & $(0.40-3.17)$ & 0.830 \\
\hline \multicolumn{10}{|c|}{ Mutation Status } \\
\hline NRAS vs. others & 1.42 & $(0.19-10.63)$ & 0.734 & 0.64 & $(0.20-2.10)$ & 0.464 & 0.91 & $(0.32-2.55)$ & 0.853 \\
\hline Wild vs. others & 1.27 & $(0.17-9.52)$ & 0.815 & 1.57 & $(0.51-4.84)$ & 0.437 & 0.79 & $(0.28-2.22)$ & 0.655 \\
\hline \multicolumn{10}{|c|}{ Immunotherapy } \\
\hline IT association & 1.33 & $(0.13-13.74)$ & 0.809 & 0.55 & $(0.11-2.73)$ & 0.464 & 0.63 & $(0.16-2.47)$ & 0.502 \\
\hline \multicolumn{10}{|c|}{ Line } \\
\hline 2nd, 3rd or 4th line & 1.89 & $(0.19-19.06)$ & 0.589 & 5.06 & $(1.05-24.26)$ & 0.043 & 8.13 & $(1.73-38.21)$ & 0.008 \\
\hline Previous IT line & 1.79 & $(0.24-13.35)$ & 0.576 & 2.34 & $(0.75-7.32)$ & 0.144 & 2.78 & $(0.98-7.88)$ & 0.054 \\
\hline \multicolumn{10}{|c|}{ Overall response* } \\
\hline Progressive vs. others & 1.54 & $(0.20-11.69)$ & 0.676 & 0.69 & $(0.21-2.32)$ & 0.550 & 1.00 & $(0.34-2.93)$ & 1.000 \\
\hline
\end{tabular}

SSM was significantly associated with irAEs at 7 months $(O R=3.42 ; p=0.023), 1$ year $(O R=4.40 ; p=0.016)$ and 2 years $(O R=5.33 ; p=0.156)$. The results at 2 years are not significant due to poor outcomes. ALM was significantly associated with irAEs at 2 years $(O R=24.7 ; p=0.037)$ and was not significantly associated with irAES at 1 year $(O R=4.50$; $p=0.298)$ and 7 months $(O R=3.05 ; p=0.438)$. These results were omitted from Table 3 due to the small sample size (two ALM melanoma patients).

There was a significant risk for late-onset irAEs if patients had received previous oncological treatments (irrespective of whether these treatments were immunotherapy) at 7 months $(O R=8.13 ; p=0.008), 1$ year $(O R=5.06 ; p=0.043)$ and 2 years $(O R=1.89$; $p=0.589$ ).

The other parameters-sex, mutational status, association of immunotherapy (PD1i and CTLA4i) and overall response-were not significantly associated with late-onset irAEs. We then pooled patients in two groups, those under 75 years of age and those over 75 years of age. The respective ORs at 7 months, 1 year and 2 years were $0.52,0.61$ and 0.59 , but these results were not significant. The results were similar when 70 years of age was used as the cutoff.

The results were not significant with an $\mathrm{OR}=1.57(0.19-10.6)$ and $p=0.390$ at 7 months, an $\mathrm{OR}=1.28(0.41-3.96)$ and $p=0.670$ at 1 year and an $\mathrm{OR}=1.42(0.56-4.34)$ and $p=0.733$ at 2 years when comparing nivolumab administered at $3 \mathrm{mg} / \mathrm{kg}$ and at a flat dose of $480 \mathrm{mg}$.

All significant parameters in the univariate analysis were subsequently analyzed by a multivariate analysis. The results are summarized in Table 5 .

SSM was confirmed to be a significant risk factor by the multivariate analysis $(\mathrm{aOR}=4.46$ $p=0.012$ at 7 months and aOR $=5.23 p=0.01$ at 1 year). Previous oncological drug administration before immunotherapy remained a risk factor in the multivariate analysis. Due to a lack of data, no results are available for irAEs at the 2-year time point. 
Table 5. Factors associated with late-onset events (7 months, 1 year, 2 years) by multivariate analyscheme 95 . (CI $=l: 95 \%$ confidence interval; $p$ : p-value for multivariate logistic regression).

\begin{tabular}{|c|c|c|c|c|c|c|c|c|c|}
\hline \multirow{2}{*}{ Characteristics } & \multicolumn{3}{|c|}{ Late-Onset AEs ( $\geq 2$ Years, $n=4$ ) } & \multicolumn{3}{|c|}{ Late-Onset AEs ( $\geq 1$ Years, $n=15$ ) } & \multicolumn{3}{|c|}{ AEs ( $\geq 7$ Months, $n=20$ ) } \\
\hline & aOR & $95 \% \mathrm{CI}$ & $p$ & aOR & $95 \% \mathrm{CI}$ & $p$ & aOR & $95 \% \mathrm{CI}$ & $p$ \\
\hline \multicolumn{10}{|c|}{ Type of melanoma } \\
\hline SSM vs. others & & & & 5.23 & $(1.48-18.43)$ & 0.01 & 4.46 & $(1.39-14.28)$ & 0.012 \\
\hline \multicolumn{10}{|c|}{ Line } \\
\hline 2,3 or 4 line & & & & 6.17 & $(1.21-31.54)$ & 0.029 & 10.21 & $(2.03-51.40)$ & 0.005 \\
\hline
\end{tabular}

\section{Discussion}

Our study shows that SSM and previous oncological drug administration before immunotherapy are significant risk factors for late-onset irAEs, i.e., irAEs that arise over 2 years after beginning immunotherapy.

The Kaplan-Meier analysis revealed that the median onset time of grade III-IV irAES is 128 days after the initiation of ICI therapy; in contrast, 91 days is reported in the literature [18] to be the median onset time of all-grade irAEs. Adverse events are commonly observed in melanoma patients treated with immunotherapy, and almost $20 \%$ of patients experience grade III-IV treatment-related adverse events [4,6]. The most common AEs are hepatogastroenterologic complications (AST or ALT increased, diarrhea, colitis, hepatitis) or pneumonitis [15,19]. In our real-life data study, the notable grade III-IV adverse events observed were colitis $(n=15,19 \%)$, hepatitis $(n=13,16 \%)$, cholangitis $(n=7,9 \%)$ and pneumonitis $(n=4,5 \%)$, which is consistent with those observed in a meta-analysis of clinical trial data [19]. Some studies have reported that fewer adverse events are associated with nivolumab [20-22], but these results were not statistically significant.

Four late-onset irAEs occurred over 2 years in our cohort of 79 patients. One patient experienced pruritus and another experienced hepatitis, which are well-known and frequently described irAEs associated with PDis. Additionally, one patient experienced myocarditis and one experienced optic neuritis. An extensive physical examination revealed no etiology underlying the patient's pruritus apart from immunotherapy. Neurologic or cardiac irAEs in patients treated with ICIs are uncommon $(<1 \%)$ but usually severe, with high morbidity and mortality rates [23]. We identified a patient with grade III irAE optic neuritis that occurred 1249 days after the initiation of immunotherapy. There were no indications of PD1i-induced Vogt-Koyanagi-Harada disease (VKH), which consists of uveitis, optic neuritis and choroiditis [24]. There are a few cases reported in the literature of profound vision loss due to optic neuritis occurring 4 months after immunotherapy initiation [25]. We identified a patient with grade IV irAE myocarditis that occurred 759 days after the initiation of immunotherapy. Autoimmune myocarditis secondary to the immune infiltration of CD4+ T cells into the heart [26] is a rare but often fatal event associated with checkpoint-inhibitor immunotherapy. To the best of our knowledge, no other studies have focused on late-onset irAEs; however, some case reports exist regarding late-onset cardiological irAEs [27,28], late-onset pneumonitis [29] and gastroenterological events [30]. All late-onset irAEs occurred with PD1i and none with combination therapy. The combination of PD1i-CTAL4i is more likely to provide acute irAEs than late-onset irAES, especially because it is administrated only for the first four regimens (i.e., for 9 weeks). After that, patients are treated with nivolumab only.

Our study revealed that there is a significant risk for late-onset irAEs if patients have received previous oncological treatments (irrespective of whether these were immunotherapies), indicating that cumulative exposure to treatment agents increases the risk of irAEs. A significant dose-dependent increase in PD1i-associated adverse events has been reported [21,31]; however, no similar results are available comparing a $3 \mathrm{mg} / \mathrm{kg}$ nivolumab dose $(n=46)$ to a flat nivolumab dose $(n=18) \mathrm{OR}=1.42(0.56-4.34) ; p=0.733$, probably due to an imbalance in patient recruitment between these two groups. Given the mechanism of action of immune-checkpoint inhibitors, which promote T-cell activation and enhance 
T-cell activity, specific adverse events that are mostly of immunologic origin typically arise. This explains why there are more late-onset irAEs with a cumulative dose of PD1i, whereas early irAEs are more dose-dependent, rather than related to the drug mechanisms.

In addition, our results indicate that there is no association between late-onset irAEs and an initial favorable response since the ODs are 1, 0.69 and 1.54 at 7 months, 1 year and 2 years, respectively. These results are in agreement with those previously reported [32], in which irAE occurrence, irrespective of early or late onset, was found to be associated with improved PFS outcomes and better OS rates. This observation was similar regarding radiologic immune-mediated adverse reactions (i.e., colitis, pneumonitis, myocarditis) [33].

Despite the immune senescence and immune system deregulation that affects antigenpresenting cells, T lymphocytes and effector molecules in the geriatric population [34], immunotherapy treatment seems to be effective and safe for patients over 80 years of age [35]. Some researchers have reported that older patients have a better response and fewer irAES than younger patients treated with PD-1 inhibitors [36]. Others have revealed that response rates and toxicity outcomes in patients treated with checkpoint inhibitors are not altered with increasing age or comorbidity [37]. The number of comorbidities and ECOG status, or WHO performance status, are variables not associated with severe irAEs [38]. In our study, we observed a trend indicating that age over 75 years could be a protective factor (OR $0.52,0.61$ and 0.59 at 7 months, 1 year and 2 years, respectively); however, the results were not significant.

Most melanomas result from the inability of a skin phototype to repair the intracellular damage induced by UV radiation. Sunburn episodes in early childhood appeared to be more strongly related to SSM than to other variants [39]. The results of a recent study showed that helioderma could be a predictive clinical biomarker of a favorable PD-1i response [40]. Our study confirmed that SSM melanoma is a risk factor for irAEs at 7 months $(O R=3.42 ; p=0.023), 1$ year $(O R=4.40 ; p=0.016)$ and 2 years $(O R=5.33$; $p=0.156$ ). These results could be explained by the long horizontal growth pattern of SSM, enabling it to achieve closer and longer contact with the immune environment than other melanomas, allowing for more contact with cytotoxic lymphocytes. Tissueresident memory $\mathrm{CD} 8^{+} \mathrm{T}$ cells ( $\mathrm{T}_{\mathrm{RM}}$ cells) promote a durable melanoma-immune system equilibrium that is confined to the epidermal layer of the skin [41]. This explains the higher incidence of irAES associated with SSM on the one hand; on the other hand, it leads to better PFS and OS outcomes among SSM patients.

As this was a monocentric study, our results are not powerful enough to make recommendations. However, our results confirm the necessity of performing a larger multicentric cohort study analyzing data from all participating centers from the national RicMel database.

\section{Conclusions}

Our study suggests that patients with SSM and those who have received previous oncological treatments are more likely to experience late-onset grade III-IV irAES. No other study using real-life data has been performed to investigate late-onset irAES. Further multicentric studies with a wider recruitment of patients should be performed to confirm our findings.

The long-term safety of PD-1i was determined to be acceptable, since we reported very few late-onset irAEs. However, the potential for grade III-IV irAEs justifies stopping immunotherapy after achieving a one-year complete response to avoid these adverse events.

It could be relevant to modify how clinicians monitor irAEs, especially in young patients with melanoma and a long treatment duration. Even after achieving a one-year complete response, these patients should be closely followed over the long-term to quickly identify and address potential adverse events.

Ongoing prospective clinical trials will further assess the impact of immunotherapy on all grade III-IV late-onset adverse effects and provide information on how to carefully monitor individual patient risk. 
Author Contributions: Conceptualization, B.D. and A.K.; methodology, J.-M.L.; software, J.-M.L.; validation, B.D. and A.D.; formal analysis, J.-M.L. and E.V.; investigation, J.-M.L.; resources, B.D. and A.K. and E.V.; data curation, E.V.; writing-original draft preparation, J.-M.L.; writing-review and editing, J.-M.L.; visualization, J.-M.L.; supervision, B.D. and A.D.; project administration, B.D.; All authors have read and agreed to the published version of the manuscript.

Funding: This research received no external funding.

Institutional Review Board Statement: The RicMel database (Clinical Trials $\mathrm{n}^{\circ}$. NCT03315468) gathers data from 49 participating centers in different French regions. It received ethics committee approval on February 9th, 2012 (no. 12.108) from the Independent Ethics Committee of Paris and authorization from the French Data Protection Agency (CNIL, DR-2012- 259, 28 May 2012).

Informed Consent Statement: Informed consent was obtained from all subjects involved in the study.

Data Availability Statement: The data presented in this study are available on request from the corresponding author. The data are not publicly available because they are obtained and stored from the RicMel database.

Conflicts of Interest: The authors declare no conflict of interest.

\section{References}

1. Lin, Z.; Chen, X.; Li, Z.; Luo, Y.; Fang, Z.; Xu, B.; Han, M. PD-1 Antibody Monotherapy for Malignant Melanoma: A Systematic Review and Meta-Analysis. PLoS ONE 2016, 11, e0160485. [CrossRef]

2. Santé Publique France. Available online: https://www.cancer-environnement.fr/340-Melanome-cutane.ce.aspx (accessed on 23 February 2021).

3. Ribas, A. Tumor Immunotherapy Directed at PD-1. New Engl. J. Med. 2012, 366, 2517-2519. [CrossRef]

4. Topalian, S.L.; Sznol, M.; McDermott, D.F.; Kluger, H.M.; Carvajal, R.D.; Sharfman, W.H.; Brahmer, J.R.; Lawrence, D.P.; Atkins, M.B.; Powderly, J.D.; et al. Survival, Durable Tumor Remission, and Long-Term Safety in Patients with Advanced Melanoma Receiving Nivolumab. J. Clin. Oncol. 2014, 32, 1020-1030. [CrossRef]

5. Mellman, I.; Coukos, G.; Dranoff, G. Cancer immunotherapy comes of age. Nat. Cell Biol. 2011, 480, 480-489. [CrossRef]

6. Topalian, S.L.; Hodi, F.S.; Brahmer, J.R.; Gettinger, S.N.; Smith, D.C.; McDermott, D.F.; Powderly, J.D.; Carvajal, R.D.; Sosman, J.A.; Atkins, M.B.; et al. Safety, activity, and immune correlates of anti-PD-1 antibody in cancer. N. Engl. J. Med. 2012, 366, 2443-2454. [CrossRef] [PubMed]

7. Freeman, G.J.; Long, A.J.; Iwai, Y.; Bourque, K.; Chernova, T.; Nishimura, H.; Fitz, L.J.; Malenkovich, N.; Okazaki, T.; Byrne, M.C.; et al. Engagement of the Pd-1 Immunoinhibitory Receptor by a Novel B7 Family Member Leads to Negative Regulation of Lymphocyte Activation. J. Exp. Med. 2000, 192, 1027-1034. [CrossRef] [PubMed]

8. $\quad$ Dong, H.; Strome, S.E.; Salomao, D.R.; Tamura, H.; Hirano, F.; Flies, D.B.; Roche, P.C.; Lu, J.; Zhu, G.; Tamada, K.; et al. Tumorassociated B7-H1 promotes T-cell apoptosis: A potential mechanism of immune evasion. Nat. Med. 2002, 8, 793-800. [CrossRef] [PubMed]

9. Iwai, Y.; Ishida, M.; Tanaka, Y.; Okazaki, T.; Honjo, T.; Minato, N. Involvement of PD-L1 on tumor cells in the escape from host immune system and tumor immunotherapy by PD-L1 blockade. Proc. Natl. Acad. Sci. USA 2002, 99, 12293-12297. [CrossRef]

10. Lipson, E.J.; Sharfman, W.H.; Drake, C.G.; Wollner, I.; Taube, J.M.; Anders, R.A.; Xu, H.; Yao, S.; Pons, A.; Chen, L.; et al. Durable Cancer Regression Off-Treatment and Effective Reinduction Therapy with an Anti-PD-1 Antibody. Clin. Cancer Res. 2013, 19, 462-468. [CrossRef] [PubMed]

11. Seidel, J.; Otsuka, A.; Kabashima, K. Anti-PD-1 and Anti-CTLA-4 Therapies in Cancer: Mechanisms of Action, Efficacy, and Limitations. Front. Oncol. 2018, 8, 86. [CrossRef]

12. Li, X.; Shao, C.; Shi, Y.; Han, W. Lessons learned from the blockade of immune checkpoints in cancer immunotherapy. J. Hematol. Oncol. 2018, 11, 1-26. [CrossRef] [PubMed]

13. Wang, D.Y.; Salem, J.; Cohen, J.V.; Chandra, S.; Menzer, C.; Ye, F.; Zhao, S.; Das, S.; Beckermann, K.E.; Ha, L.; et al. Fatal Toxic Effects Associated with Immune Checkpoint Inhibitors: A Systematic Review and Meta-analysis. JAMA Oncol. 2018, 4, 1721-1728. [CrossRef]

14. Almutairi, A.R.; McBride, A.; Slack, M.; Erstad, B.L.; Abraham, I. Potential Immune-Related Adverse Events Associated with Monotherapy and Combination Therapy of Ipilimumab, Nivolumab, and Pembrolizumab for Advanced Melanoma: A Systematic Review and Meta-Analysis. Front. Oncol. 2020, 10, 91. [CrossRef] [PubMed]

15. Freeman-Keller, M.; Kim, Y.; Cronin, H.; Richards, A.; Gibney, G.T.; Weber, J. Nivolumab in Resected and Unresectable Metastatic Melanoma: Characteristics of Immune-Related Adverse Events and Association with Outcomes. Clin. Cancer Res. 2016, 22, 886-894. [CrossRef]

16. Naidoo, J.; Page, D.B.; Li, B.; Connell, L.C.; Schindler, K.; Lacouture, M.; Postow, M.A.; Wolchok, J.D. Toxicities of the anti-PD-1 and anti-PD-L1 immune checkpoint antibodies. Ann. Oncol. 2015, 26, 2375-2391. [CrossRef] 
17. Danson, S.; Hook, J.; Marshall, H.; Smith, A.; Bell, S.; Rodwell, S.; Corrie, P. Are we over-treating with checkpoint inhibitors? Br. J. Cancer 2019, 121, 629-630. [CrossRef]

18. Favara, D.M.; Spain, L.; Au, L.; Clark, J.; Daniels, E.; Diem, S.; Chauhan, D.; Turajlic, S.; Powell, N.; Larkin, J.M.; et al. Five-year review of corticosteroid duration and complications in the management of immune checkpoint inhibitor-related diarrhoea and colitis in advanced melanoma. ESMO Open 2020, 5, e000585. [CrossRef]

19. Wang, Y.; Zhou, S.; Yang, F.; Qi, X.; Wang, X.; Guan, X.; Shen, C.; Duma, N.; Vera Aguilera, J.; Chintakuntlawar, A.; et al. Treatment-Related Adverse Events of PD-1 and PD-L1 Inhibitors in Clinical Trials: A Systematic Review and Meta-analysis. JAMA Oncol. 2019, 5, 1008-1019. [CrossRef] [PubMed]

20. Larkin, J.; Chiarion-Sileni, V.; Gonzalez, R.; Grob, J.J.; Cowey, C.L.; Lao, C.D.; Schadendorf, D.; Dummer, R.; Smylie, M.; Rutkowski, P.; et al. Combined Nivolumab and Ipilimumab or Monotherapy in Untreated Melanoma. N. Engl. J. Med. 2015, 373, 23-34. [CrossRef] [PubMed]

21. Robert, C.; Long, G.V.; Brady, B.; Dutriaux, C.; Maio, M.; Mortier, L.; Hassel, J.C.; Rutkowski, P.; McNeil, C.; Kalinka-Warzocha, E.; et al. Nivolumab in previously untreated melanoma without BRAF mutation. N. Engl. J. Med. 2015, 372, 320-330. [CrossRef] [PubMed]

22. Weber, J.S.; D'Angelo, S.P.; Minor, D.; Hodi, F.S.; Gutzmer, R.; Neyns, B.; Hoeller, C.; Khushalani, N.I.; Miller, W.H.; Lao, C.D.; et al. Nivolumab versus chemotherapy in patients with advanced melanoma who progressed after anti-CTLA-4 treatment (CheckMate 037): A randomised, controlled, open-label, phase 3 trial. Lancet Oncol. 2015, 16, 375-384. [CrossRef]

23. Diamantopoulos, P.T.; Tsatsou, K.; Benopoulou, O.; Bonou, M.; Anastasopoulou, A.; Mastrogianni, E.; Gogas, H. Concomitant development of neurologic and cardiac immune-related adverse effects in patients treated with immune checkpoint inhibitors for melanoma. Melanoma Res. 2020, 30, 484-491. [CrossRef]

24. Witmer, M.T. Treatment of Ipilimumab-Induced Vogt-Koyanagi-Harada Syndrome with Oral Dexamethasone. Ophthalmic Surg. Lasers Imaging Retin. 2017, 48, 928-931. [CrossRef]

25. Wilson, M.; Guld, K.; Galetta, S.; Walsh, R.D.; Kharlip, J.; Tamhankar, M.; Mcgettigan, S.; Schuchter, L.M.; Fecher, L.A. Acute visual loss after ipilimumab treatment for metastatic melanoma. J. Immunother. Cancer 2016, 4, 66. [CrossRef]

26. Reuben, A.; De Macedo, M.P.; McQuade, J.; Joon, A.; Ren, Z.; Calderone, T.; Conner, B.; Wani, K.; Cooper, Z.; Tawbi, H.; et al. Comparative immunologic characterization of autoimmune giant cell myocarditis with ipilimumab. OncoImmunology 2017, 6, e1361097. [CrossRef] [PubMed]

27. Dasanu, C.A.; Jen, T.; Skulski, R. Late-onset pericardial tamponade, bilateral pleural effusions and recurrent immune monoarthritis induced by ipilimumab use for metastatic melanoma. J. Oncol. Pharm. Pract. Off Publ. Int. Soc. Oncol. Pharm. Pract. 2017, 23, 231-234. [CrossRef]

28. Yamaguchi, S.; Morimoto, R.; Okumura, T.; Yamashita, Y.; Haga, T.; Kuwayama, T.; Yokoi, T.; Hiraiwa, H.; Kondo, T.; Sugiura, Y.; et al. Late-Onset Fulminant Myocarditis with Immune Checkpoint Inhibitor Nivolumab. Can. J. Cardiol. 2018, 34, 812.e1-812.e3. [CrossRef] [PubMed]

29. Safa, H.; Bhosale, P.; Weissferdt, A.; Oliva, I.C.G. Difficulties in differentiating between checkpoint inhibitor pneumonitis and lung metastasis in a patient with melanoma. Immunotherapy 2020, 12, 293-298. [CrossRef] [PubMed]

30. Akel, R.; Anouti, B.; Tfayli, A. Late-Onset Inflammatory Bowel Disease-Like Syndrome after Ipilimumab Therapy: A Case Report. Case Rep. Oncol. 2017, 10, 456-461. [CrossRef] [PubMed]

31. Ribas, A.; Puzanov, I.; Dummer, R.; Schadendorf, D.; Hamid, O.; Robert, C.; Hodi, F.S.; Schachter, J.; Pavlick, A.C.; Lewis, K.D.; et al. Pembrolizumab versus investigator-choice chemotherapy for ipilimumab-refractory melanoma (KEYNOTE-002): A randomised, controlled, phase 2 trial. Lancet Oncol. 2015, 16, 908-918. [CrossRef]

32. Indini, A.; Di Guardo, L.; Cimminiello, C.; Prisciandaro, M.; Randon, G.; De Braud, F.; del Vecchio, M. Immune-related adverse events correlate with improved survival in patients undergoing anti-PD1 immunotherapy for metastatic melanoma. J. Cancer Res. Clin. Oncol. 2019, 145, 511-521. [CrossRef]

33. Ezponda Casajús, A.; Calvo Imirizaldu, M.; de Torres Tajes, J.P.; García-Baizán, A.; Castañón Álvarez, E.; Cano Rafart, D.; Vivas Pérez, I.; Bastarrika Alemañ, G. Immune-related adverse events as predictors of response in cancer patients undergoing immunotherapy. Radiologia 2020, 62, 131-138. [CrossRef]

34. Barailler, H.; Salomon, G.; Dutriaux, C.; Prey, S.; Gérard, E.; Dousset, L.; Mertens, C.; Beylot-Barry, M.; Meyer, N.; Pham-Ledard, A. Adverse events, need for hospitalization and systemic immunosuppression in very older patients (over 80 years) treated with anti-PD-1 for metastatic melanoma. J. Geriatr. Oncol. 2020, 11, 1340-1343. [CrossRef] [PubMed]

35. Leroy, V.; Gerard, E.; Dutriaux, C.; Prey, S.; Gey, A.; Mertens, C.; Beylot-Barry, M.; Pham-Ledard, A. Adverse events need for hospitalization and systemic immunosuppression in very elderly patients (over 80 years) treated with ipilimumab for metastatic melanoma. Cancer Immunol. Immunother. 2019, 68, 545-551. [CrossRef] [PubMed]

36. Kugel, C.H.; Douglass, S.M.; Webster, M.; Kaur, A.; Liu, Q.; Yin, X.; Weiss, S.A.; Darvishian, F.; Al-Rohil, R.N.; Ndoye, A.; et al. Age Correlates with Response to Anti-PD1, Reflecting Age-Related Differences in Intratumoral Effector and Regulatory T-Cell Populations. Clin. Cancer Res. 2018, 24, 5347-5356. [CrossRef] [PubMed]

37. de Glas, N.A.; Bastiaannet, E.; van den Bos, F.; Mooijaart, S.P.; van der Veldt, A.A.M.; Suijkerbuijk, K.P.M.; Aarts, M.J.B.; van den Berkmortel, F.W.P.J.; Blank, C.U.; Boers-Sonderen, M.J.; et al. Toxicity, Response and Survival in Older Patients with Metastatic Melanoma Treated with Checkpoint Inhibitors. Cancers 2021, 13, 2826. [CrossRef] [PubMed] 
38. Verheijden, R.J.; May, A.M.; Blank, C.U.; van der Veldt, A.A.; Boers-Sonderen, M.J.; Aarts, M.J.; Berkmortel, F.W.V.D.; Eertwegh, A.J.V.D.; de Groot, J.W.B.; van der Hoeven, J.J.; et al. Lower risk of severe checkpoint inhibitor toxicity in more advanced disease. ESMO Open 2020, 5, e000945. [CrossRef] [PubMed]

39. Naldi, L.; Altieri, A.; Imberti, G.L.; Gallus, S.; Bosetti, C.; La Vecchia, C. Sun Exposure, Phenotypic Characteristics, and Cutaneous Malignant Melanoma. An Analysis According to Different Clinico-Pathological Variants and Anatomic Locations (Italy). Cancer Causes Control. 2005, 16, 893-899. [CrossRef]

40. Russo, D.; Poizeau, F.; Dinulescu, M.; Baggio, R.; Orion, C.; Soethoudt, C.; Saillard, C.; Man, S.L.P.; Lesimple, T.; Pracht, M.; et al. L'héliodermie autour du mélanome primitif comme marqueur clinique prédictif de réponse aux anti-PD-1. Ann. Dermatol. Vénéréologie 2020, 147, A108-A1089. [CrossRef]

41. Park, S.L.; Buzzai, A.; Rautela, J.; Hor, J.L.; Hochheiser, K.; Effern, M. Tissue-resident memory CD8+ T cells promote melanomaimmune equilibrium in skin. Nature 2019, 565, 366-371. [CrossRef] 